\title{
Expression pattern of heat shock protein genes in sheep
}

Fawzy E. Younis

Animal and Poultry Physiology Department, Animal and Poultry Division, Desert Research Center, P.O. 11753m, Egypt

\section{ARTICLE HISTORY}

Received: 24.11.2019

Revised: 07.01.2020

Accepted: 09.01.2020

Address correspondence to Fawzy Younis; Tel: +201018090085;

E-mail: alphayounis@gmail.com

\section{ABSTRACT}

Objective: To recognize the expression patterns of HSP70 and HSP90 genes in two local breeds of Sheep.

Design: Descriptive study.

Animals: Fifty ewes (25 Barki and 25 Abu Dlik).

Procedures: This investigation was carried out on fifty sheep at the northwest coast and southeast of triangle Halayeb and Shalateen during the months of March and May 2018 and 2019 (average day time temperatures: $25-35{ }^{\circ} \mathrm{C}$; relative humidity: 55-65\%). Total RNA was extracted using easy-RED ${ }^{\text {TM }}$ Total RNA Extraction Kit. The primers for qPCR were designed on the basis of prior sequence information available at National Center for Biotechnology Information (NCBI) for the target HSP70 and 90 genes. The Glyceraldehyde3-phosphate dehydrogenase (GAPDH)) gene, housekeeping gene, was used for normalization of qPCR data. The desired genes were amplified for relative expression measurements. Tumor necrosis factor- $\alpha$ (TNF- $\alpha$ ), Interleukin-1 $\beta$ (IL-1 $\beta$, IL-6, IL-10, IL-12) were assayed.

Results: The expression levels of the HSP70 and HSP90 genes and the genes in Abu Dlik sheep were observed to be relatively up-regulated than those in Barki sheep. Abu Dlik breed exhibited an up-regulated mRNA level of Hsp70 and Hsp90 genes (1.70440938 vs 1.362954) while the Barki breed showed a down-regulated pattern (0.8550442 vs 0.4289764). In Abu Dlik ewes HSP70 gene exhibited a higher mRNA level than HSP90 mRNA.

Conclusion and clinical relevance: Gene expression patterns of HSP70 and HSP90, as well as cytokines modulations can be used as a biological marker and a reference point in sheep to identify, manipulate and cross-breed for improving the genetic potential and adaptability to tolerate harsh environmental conditions, especially heat stress.

Keywords: HSP70, HSP90, Real time PCR, Cytokines, Sheep.

\section{INTRODUCTION}

Environmental stress is a key factor driving the genome guideline, evolutionary history, and geographical distribution of organisms [1]. Worldwide normal temperatures are relied upon to increment by around $1-7{ }^{\circ} \mathrm{C}\left(2-13^{\circ} \mathrm{F}\right)$ before the century is over. In spite of the fact that this change may not sound so huge, the issue is that even little changes in worldwide normal temperature can prompt enormous changes in the earth. Evolutionary changes in animal populations can be rapid, particularly as a consequence of human-induced environmental disturbances [1, 2]. These include the adaptation in plants, invertebrates, and vertebrates to heavy metals, adaptation to chemical and thermal emissions from factories, responses to salinity, evolutionary responses to overfishing, and adaptation to global temperature changes [3].

The selection of thermoresistant animals is an effective way to improve the productivity of livestock during high environmental temperature. Identification and exploitation of genotypes having thermo-tolerance in livestock are a major concern in the changing climate scenario which can have a great impact on livestock productivity. The environmental stress, particularly heat stress (HS) is the major concern in the livestock sector $[4,5]$.

Heat chock increases heat shock proteins expression in skeletal and cardiac muscles, which may enhance the tolerance to stress and increase the survival rate of the stressed cells [6]. Heat shock proteins are a family of proteins produced in all cells and tissues in response to the exposure to stressful conditions, such as HS [7]. The most important of these with respect to HS is heat shock protein70 kDa (HSP70) [6]. The HSPs have been studied extensively, especially regarding their regulation, localization, and function in the cell [3]. Stress-induced HSP accumulation is associated with thermo-tolerance, the ability to survive otherwise lethal heat stress, and later with tolerance to a variety of stresses, including ischemia [8, 9], ultraviolet irradiation [10], and cytokines such as tumor necrosis factor- $\alpha$ (TNF- $\alpha)$ [11]. 
Thermotolerant gene expression and elevated HSP levels are observed to be the ultimate response through which the cell sustains the impact of HS making it a full proof biomarker for the condition. The HSP is one of the cellular proteins found most abundantly under non-stress conditions also $[8,9]$.

One of the primary ways through which scientist across the globe are establishing the severity of HS is by expression of HSP $[12,13]$. Over expression of HSPs provide protection against hyperthermia, circulatory shock, and cerebral ischemia during heat stroke which signifies the central role of HSP in cryoprotection [14]. The HSPs have a chaperonic activity ensuring the folding, unfolding and refolding of stressdenatured proteins [15]. Hydrophobic protein sequences liberated by denaturation gets bounded with the HSPs which otherwise would interact with other neighbour proteins resulting in loss of protein function.

Some research has moved on to identifying specific marker genes that underlie these genetic variants [16]. Banks of markers are emerging that can be used in the treatment of human diseases, indicating the likely vulnerability of individuals to different diseases and aiding in drug applications [17]. The mechanisms and cellular roles of Hsp70 have emerged many opportunities to design or screen for modulators of Hsp70 function $[18,19]$.

It is known that some local breeds have more heat tolerance compared to other breeds. Identification and exploitation of genotypes having thermo-tolerance in small ruminants are a major concern in the changing climate scenario which can have a great impact on livestock productivity. Therefore, the aim of the current study was to investigate the expression pattern of heat shock protein HSP70, and HSP90 genes in Barki and Abu Dlik sheep.

\section{MATERIALS AND METHODS}

\subsection{Animals and blood collection}

This investigation was carried out on fifty sheep at the northwest coast and southeast of triangle Halayeb and Shalateen during the months of March and May 2018 and 2019 (average day time temperatures: $25-35{ }^{\circ} \mathrm{C}$; relative humidity: $55-65 \%)$. Animals of $2-2.5$ years old apparently free from anatomical abnormalities and with average body weight of 30-40 kg were selected from both herds. Animals were maintained under open housing conditions with access to $a d$ lib., water, good quality green, dry feeds and supplementation of concentrate mixture. Blood samples $(10 \mathrm{ml})$ were collected from animals by jugular vein, in tubes containing anticoagulant heparin and kept frozen $\left(-20^{\circ} \mathrm{C}\right)$ until analysis.

\subsection{RNA Extraction}

Total RNA was extracted using easy-RED ${ }^{\text {TM }}$ Total RNA Extraction Kit (17063, iNtRON, Korea). Samples of $250 \mu \mathrm{l}$ of blood were prepared in
$1.5 \mathrm{ml}$ microcentrifuge tube, and $750 \mu \mathrm{l}$ of easy-REDTM Solution was added. The samples were mixed in room temperature for $15 \mathrm{sec}$ by vigorous vortex and the tubes were incubated at room temperature $\left(15 \sim 30{ }^{\circ} \mathrm{C}\right)$ for $5 \mathrm{~min}$. Following homogenization, insoluble material was removed from homogenate by centrifugation at 13,000 rpm for $3 \mathrm{~min}$. The resulting pellet contained extracellular membranes, polysaccharides, and high molecular weight DNA, while supernatant contained RNA. An amount of $250 \mu \mathrm{l}$ of Chloroform was added and the sample was mixed in room temperature for $15 \mathrm{sec}$ by a vigorous vortex. The tubes were then incubated at room temperature for $3 \mathrm{~min}$. The purpose of adding the chloroform was to separate the phenol layer from aqueous layer and eventually to isolate RNA and genomic DNA/protein. After that the tubes were centrifuged at $13,000 \mathrm{rpm}$ for $3 \mathrm{~min}$ and a $400 \mu \mathrm{l}$ of the upper fluid were transformed to a new $1.5 \mathrm{ml}$ centrifuge tube. Equal volume $(400 \mu \mathrm{l})$ of isopropanol (2-propanol) was added and mixed well by inverting the tube $4 \sim 5$ times. The tubes were incubated for $5 \mathrm{~min}$ at room temperature. The tubes were centrifuged at $13,000 \mathrm{rpm}$ for $3 \mathrm{~min}$, carefully the supernatant was removed without disturbing the pellet. Then $1 \mathrm{ml}$ of $70 \%$ ethanol was added and the solution was mixed well by inverting the tube 4 $\sim 5$ times. The mixture was centrifuged for $3 \mathrm{~min}$ at 13,000 rpm. Carefully the supernatant was discarded without disturbing the pellet. Then the remaining RNA pellet was dried. RNA pellet was dissolved by using $30 \mathrm{ml}$ of RNase free water. The purity of RNA was analyzed by agarose $(1.5 \%)$ gel electrophoresis.

\section{3. The $C D N A$ synthesis and real time $P C R$ ( $q P C R$ )}

The cDNA was prepared using The HiSen Script ${ }^{\mathrm{TM}} \mathrm{RH}(-)$ cDNA Synthesis Kit (INtron Biotecnology, Korea). The cDNA products were analyzed by agarose $(1.5 \%)$ gel electrophoresis. Relative expression level of mRNA transcripts of HSP70 and 90 genes was measured by quantitative real-time PCR (qPCR). The primers for qPCR were designed on the basis of prior sequence information available at National Center for Biotechnology Information (NCBI, https://www.ncbi.nlm.nih.gov/), of the target genes (HSP70 and 90) through primer3 software, http://bioinfo.ut.ee/primer3-0.4.0/, one housekeeping (Glyceraldehyde-3-phosphate dehydrogenase (GAPDH)) gene was amplified for the relative expression measurements (Table 1).

\subsection{Biochemical parameters of cytokines}

Interleukin-6 (IL-6), Interleukin-10 (IL-10) and Interleukin12 (IL-12) were determined using Quantikine IL ELISA Kits [20]. Interleukin-1 $\beta$ (IL-1 $\beta$ ) was determined using Quantikine IL-1 $\beta$ ELISA Kit [21, 22]. Kits of cytokines were purchased from Sigma (Aldrich-Sigma Company, CA, U S A). 


\section{5. Statistical analysis}

Statistical analysis of data was carried out by SPSS version 17 (SPSS, P.C, 2004). Un-paired $t$-tests for assessment the significance differences between variables were used. Results were considered significant only at the level of $(p<0.05)$. For evaluations of selected cytokines, the following equation was used.

$$
Y i j=\mu+B i+e i j
$$

Where $Y_{i j}$ is the $j$-th observed value of the response variable for $i$-th group, $\mu$ is the general mean effect, $B i$ is the effect of $\mathrm{i}$-th breed, and eij is the error term. The multiple comparisons between different groups were done using Duncan's multiple range test (DMRT). Statistical analysis was done using SAS 9.2 software (SAS Institute Inc., Cary, NC, USA).

Table 1. Primer sequences and amplicon size of each gene target analyzed in sheep by quantitative real time PCR.

\begin{tabular}{|c|c|c|}
\hline Gene & Primer & Sequence $\left(5^{\prime} \rightarrow 3^{\prime}\right)$ \\
\hline \multirow[t]{2}{*}{ HSP70 } & Forward & GACAAGTCGGAGAACGTGCA \\
\hline & Reverse & CGTACACCTGGATCAGCAC \\
\hline \multirow[t]{2}{*}{ HSP9O } & Forward & ATTGACATCATCCCGAATC \\
\hline & Reverse & ACACCAAACTGCCCAATCAT \\
\hline \multirow[t]{2}{*}{ GAPDH } & Forward & GCAAGTTCCACGGCACAGTC \\
\hline & Reverse & CCCACTTGATGTTGGCAGGA \\
\hline
\end{tabular}

\section{RESULTS}

\section{1. Gene expression patterns}

The expression levels of the HSP70 and HSP90 genes in Abu Dlik sheep were observed to be relatively up-regulated than those in Barki sheep. Abu Dlik breed exhibited an upregulated mRNA level of Hsp70 and Hsp90 genes (1.70440938 vs 1.362954) while the Barki breed showed a down-regulated pattern (0.8550442 vs 0.4289764). In Abu Dlik ewes HSP70 gene exhibited a higher mRNA level than HSP90 mRNA. (Table 2, Figure 1).

Table 2. Fold changes of HSP-70 and HSP-90 genes in samples of local breeds of sheep.

$\begin{array}{cll}\text { Sample Name } & \text { Fold change HSP-70 } & \text { Fold change HSP-90 } \\ \text { Abu Dlik sheep } & & \\ \text { Minimum } & 1.455405587 & 1.108674711 \\ \text { Maximum } & 1.829372644 & 1.71025861 \\ \text { Average } & 1.70440938 & 1.362954 \\ \text { Barki sheep } & & \\ \text { Minimum } & 0.691039512 & 0.339972741 \\ \text { Maximum } & 0.962696903 & 0.541095273 \\ \text { Average } & 0.8550442 & 0.4289764\end{array}$

Table 3. Cytokines in plasma samples of two breeds of sheep.

\begin{tabular}{|c|c|c|c|}
\hline Variable & Abu Dlik sheep & Barki sheep & $\pm \mathrm{SE}$ \\
\hline TNF- $\alpha$ pg/ml & $22.62^{\mathrm{A}}$ & $15.57^{B}$ & $0.53^{* *}$ \\
\hline IL-1 $\beta$ (Pg/ml) & $46.96^{A}$ & $29.33^{\mathrm{B}}$ & $0.61 * *$ \\
\hline IL-6 (Pg/ml) & $47.75^{A}$ & $37.98^{\mathrm{B}}$ & $0.49 * *$ \\
\hline IL-10 pg/ml & 27.34 & 25.19 & $0.51^{\text {NS }}$ \\
\hline IL-12 pg/ml & $41.95^{\mathrm{A}}$ & $37.81^{\mathrm{B}}$ & $1.87^{* *}$ \\
\hline
\end{tabular}

NS: Not significant ${ }^{* *}$ Significant at $(\mathrm{P}<0.01)$

\section{Abu Dlik}

Figure 1. Gel electrophoresis of total RNA samples from the two breeds of heep.

Abu Dlik is a type of dry regions breed and is profoundly adapted to heat stress compared to Barki sheep is a type of semi-arid regions breed that is nearly less adapted to heat stress conditions. This indicates that the breed of Abu Dlik was better at managing heat pressure contrasted with the Barki breed of sheep.

\subsection{Cellular cytokines alterations}

Cytokine production and modulation of stress occur due to production of interleukins. Interleukins can act locally and systemically. Their action locally is to modulate cellular immune response. Systemically they change behavior, metabolism and neuroendocrine secretion. IL-6 is considered as the primary mediator of metabolic response to inflammation by inducing production of a broad array of acute phase proteins. Production of these pro inflammatory cytokines directly affects bone growth and are found to modulate the mechanism of proteins, fats and carbohydrates.

In Abu Dlik sheep highly significant increases in cytokines were induced as compared to Barki sheep. These increases may be due to the interaction between genotypes and environment which helps to tolerate desert environment. Abu Dlik sheep thus appeared more tolerant than Barki sheep to the heat stress of the desert as represented in Table 3.

\section{DISCUSSION}

Hsps are synthesized in response to different stressors indicating that they have an important role in the physiology and biology of stressed cells [3]. In general, HSPs protect organisms from various stressors such as heat, toxins, and 
pathogens. Recently, studies on animal's responses to external stressors demonstrate that such stimuli induce highly significant changes in the expression profiles of HSPs [6]. It has been found that the productive parameters like milk yield, growth, reproduction and carcass traits can be negatively impacted by heat stress $[4,5]$.

In the present study, Abu Dlik sheep exhibited higher HSP7O and HSP9O mRNA expression level than Barki sheep and this therefore indicates that Abu Dlik sheep may have higher heat tolerant activity than Barki sheep. This finding is in agreement with that of previous reports [23]. The increase in expression levels of HSP may be due in part to changes in genotype in Abo Dlik breed which made it more able to acclimate with high heat stress of the desert [24]. Therefore, plasma levels of HSP70 and HSP90 genes expression may act as an ideal biological marker for assessing the impact of heat stress in sheep.

Cytokines are synthesized in the brain, the anterior lobe of the pituitary, and the adrenal gland [25]. Also, cytokine receptors have been detected at all HPA axis levels, and therefore, each level can serve as an integration point for immune and neuroendocrine signals.

The variation in level of HSP70 gene expression has positively correlated with thermotolerance in animals [5], whereas in livestock, the relationship between differential gene expression patterns and warm resistance has been rare. In the present investigation, it was seen that heat stresstolerant (HST) Abo Dlik sheep showed higher HSP70 and HSP9O articulation than Barki sheep during periods of the study. The qualities HSP are profoundly preserved between various species; however, the HSP gene expression is breedexplicit and species-explicit. The species-explicit distinction in HSP7O isoforms is because of variation in warm resistance. The isoform expression may differ with regard to thermo-tolerance [6].

The results of the current study revealed that HSP7O and HSP9O family genes were expressed in sheep both constitutively. Upon local breeds, the expression of the genes studied was significantly higher in Abu Dlik as compared to Barki sheep. The most significant finding of this study was the increased HSP9O expression in both herds. This suggests that HSP7O and HSP9O may be used as an indicator for assessing stress especially the thermal stress response of the animal. However, further studies are warranted to validate this in other genes and to qualify HSP as an indicator of stress associated response of animals under field conditions.

Stress resilience is a mind-boggling component. The mechanism of stress resistance by HSPs has not been surely known; in any case, HSPs assume significant jobs in the handling of stress denatured proteins. HST phenotypes control heat stress in a productive way showing higher $\mathrm{Hsp} 70$ at the cell level. Be that as it may, it is important to connect the stress phenotype with adaptation, wellness, and production parameters during development periods [26]. Similarly, association of heat stress protein90 and 70 gene polymorphism with adaptability traits in Indian sheep (Ovis aries) has been documented [27].

\section{Conclusion}

Gene expression pattern of HSP7O and HSP9O can be used as a reference point in breeding to identify, manipulate and cross-breeding for the improvement of genetic potential and adaptability in sheep, and farm animals. The selection of thermo-resistant animals is an effective way to improve productivity during high environmental temperatures, especially with potential climate changes. Further research is required to verify our results and to determine the molecular mechanism to manage stress and adaptability at a cellular level.

\section{Acknowledgement}

The author would like to thank Dr. Hany A. Abdel-Salam, and Sahar Mohamed from the Marine Genomics Laboratory, Zoology Department, Faculty of Science, Benha University, Egypt, for their valuable assistance.

\section{Conflict of interest statement}

None of the authors has any conflict of interest to declare.

\section{Authors' contributions}

Younis F.E designed the experiment, collected blood samples, performed the gene expression, and wrote the manuscript.

\section{REFERENCES}

[1] Kinnison MT, Hendry AP. The pace of modern life II: from rates of contemporary microevolution to pattern and process. Microevolution rate, pattern, process: Springer; 2001 . p. 145-64. https://doi.org/10.1007/978-94-010-0585-210

[2] Hoffmann AA, Parsons PA. Evolutionary genetics and environmental stress: Oxford University Press; 1991.

[3] Alonso-Blanco, C., Aarts, M.G., Bentsink, L., Keurentjes, J.J., Reymond, M., Vreugdenhil, D., Koornneef, M., 2009. What has natural variation taught us about plant development, physiology, and adaptation? Plant Cell 21, 1877-1896. https://doi.org/10.1105/tpc.109.068114

[4] Sejian V, Maurya VP, Sharma KC, Naqvi S. Concept of multiple stresses and its significance on livestock productivity. Environmental Stress and Amelioration in Livestock Production: Springer; 2012. p. 129-50. https://doi.org/10.1007/978-3-642-29205-76

[5] Koubkova M, Knizkova L, Kunc P, Hartlova H, Flusser J, Dolezal O. Influence of high environmental temperatures and evaporative cooling on some physiological, hematological and biochemical parameters in high-yielding dairy cows. Czech J Anim Sci 2002;47:309-18.

[6] Kamboh A, Hang S, Bakhetgul M, Zhu W. Effects of genistein and hesperidin on biomarkers of heat stress in broilers under persistent summer stress. Poult Sci 2013;92:2411-8. https://doi.org/10.3382/ps.2012-02960

[7] Yahav S, Shamay A, Horev G, Bar-Ilan D, Genina O, Friedman-Einat M Effect of acquisition of improved thermotolerance on the induction of heat shock proteins in broiler chickens. Poult Sci 1997;76:1428-34 https://doi.org/10.1093/ps/76.10.1428 
[8] Marber MS, Mestril R, Chi S-H, Sayen MR, Yellon DM, Dillmann WH. Overexpression of the rat inducible $70-k D$ heat stress protein in a transgenic mouse increases the resistance of the heart to ischemic injury. J Clin Invest 1995;95:1446-56. https://doi.org/10.1172/JCI117815

[9] Archana P, Aleena J, Pragna P, Vidya M, Niyas A, Bagath M, et al. Role of heat shock proteins in livestock adaptation to heat stress. J Dairy Vet Anim Res 2017;5:00127.

[10] Barbe MF, Tytell M, Gower DJ, Welch WJ. Hyperthermia protects against light damage in the rat retina. Science 1988;241:1817-20. https://doi.org/10.1126/science.3175623

[11] Jäättelä M, Wissing D. Heat-shock proteins protect cells from monocyte cytotoxicity: possible mechanism of self-protection. J Exp Med 1993;177:231-6. https://doi.org/10.1084/jem.177.1.231

[12] Gade N, Mahapatra R, Sonawane A, Singh V, Doreswamy R, Saini M. Molecular characterization of heat shock protein 70-1 gene of goat (Capra hircus). Mol biol int 2010;2010. https://doi.org/10.4061/2010/108429

[13] Gaughan J, Mader T, Holt S, Sullivan M, Hahn G. Assessing the heat tolerance of 17 beef cattle genotypes. Int J Biometeorol 2010;54:617-27. https://doi.org/10.1007/s00484-009-0233-4

[14] Ganaie A, Ghasura R, Mir N, Bumla N, Sankar G, Wani S. Biochemical and physiological changes during thermal stress in bovines: A review. Iran J Appl Anim Sci 2013;3:423-30.

[15] Deb R, Sajjanar B, Pavani K. Bovine heat shock protein 70 and its application in cellular thermo tolerance. J Vet Sci Technol 2015;6:1000e121. https://doi.org/10.4172/2157-7579.1000e121

[16] Kleyn PW, Vesell ES. Genetic variation as a guide to drug development. Science1998;281:1820-1.

https://doi.org/10.1126/science.281.5384.1820

[17] Hiratsuka M, Sasaki T, Mizugaki M. Genetic testing for pharmacogenetics and its clinical application in drug therapy. Clin Chim Acta 2006;363:17786. https://doi.org/10.1016/j.cccn.2005.05.047

[18] Clerico EM, Tilitsky JM, Meng W, Gierasch LM. How hsp70 molecular machines interact with their substrates to mediate diverse physiological functions. J Mol biol 2015;427:1575-88. https://doi.org/10.1016/j.jmb.2015.02.004

[19] Clerico EM, Meng W, Pozhidaeva A, Bhasne K, Petridis C, Gierasch LM. Hsp70 molecular chaperones: multifunctional allosteric holding and unfolding machines. Biochem J 2019;476:1653-77. https://doi.org/10.1042/BCJ20170380

[20] Hirano T. Interleukin 6 and its receptor: ten years later. Int Rev Immunol 1998;16:249-84. https://doi.org/10.3109/08830189809042997

[21] Martinon F, Tschopp J. Inflammatory caspases and inflammasomes: master switches of inflammation. Cell Death Differ 2007;14:10. https://doi.org/10.1038/sj.cdd.4402038

[22] Sims JE, Smith DE. The IL-1 family: regulators of immunity. Nature Rev Immun 2010;10:89. https://doi.org/10.1038/nri2691

[23] Rout P, Kaushik R, Ramachandran N. Differential expression pattern of heat shock protein 70 gene in tissues and heat stress phenotypes in goats during peak heat stress period. Cell Stress Chaperones 2016;21:645-51. https://doi.org/10.1007/s12192-016-0689-1

[24] Dangi SS, Gupta M, Maurya D, Yadav VP, Panda RP, Singh G, et al. Expression profile of HSP genes during different seasons in goats (Capra hircus). Trop Anim Health Pro 2012;44:1905-12. https://doi.org/10.1007/s11250-012-0155-8

[25] Younis F, Abou El-Ezz S. How Do Cytokines Influence Stress Responses? Egyp J Basic and applied physio 2011;10:105-121.

[26] Pawar HN, Brah GS, Agrawal RK, Verma R. Molecular and immunologica characterization of heat shock protein 70 (HSP70) gene from buffalo. Proceedings of the National Academy of Sciences, India Section B: Biol Sci 2013;83:163-9. https://doi.org/10.1007/s40011-012-0113-2

[27] Singh K, Singh S, Ganguly I, Nachiappan RK, Ganguly A, Venkataramanan $\mathrm{R}$, et al. Association of heat stress protein 90 and 70 gene polymorphism with adaptability traits in Indian sheep (Ovis aries). Cell Stress Chaperones 2017:22:675-84. https://doi.org/10.1007/s12192-017-0770- 